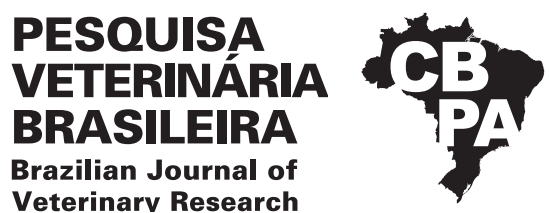

\title{
Chronic copper poisoning in beef cattle in the state of Mato Grosso, Brazil ${ }^{1}$
}

\author{
Kamila P.F. Martins² (D), Vitor H.T. Padilha ${ }^{3}$, Tércio K. Damasceno ${ }^{4}$, \\ Marcos A. Souza ${ }^{3}$, Emanoelly M.S. Silva ${ }^{2}$ (D), Marlon Ribeiro ${ }^{3}$ (D), \\ Asheley H.B. Pereira ${ }^{3}$ (D) and Edson M. Colodel ${ }^{3 *}$
}

\begin{abstract}
Martins K.P.F., Padilha V.H.T., Damasceno T.K., Souza M.A., Silva E.M.S., Ribeiro M., Pereira A.H.B. \& Colodel E.M. 2020. Chronic copper poisoning in beef cattle in the state of Mato Grosso, Brazil. Pesquisa Veterinária Brasileira 40(9):651-661. Faculdade de Medicina Veterinária, Universidade Federal do Mato Grosso, Av. Fernando Corrêa da Costa 2673, Bairro Boa Esperança, Cuiabá, MT 78068-900, Brazil. E-mail: moleta@gmail.com

Copper is an essential micromineral in animal feed; however, when consumed in excess, it can cause liver necrosis, hemolytic crisis, hemoglobinuric nephrosis and death in cattle. Although uncommon in this species, copper poisoning occurs as a result of exacerbated supplementation, deficiency of antagonist microminerals, or previous liver lesions. An outbreak of chronic copper poisoning is reported in semi-confined cattle after supplementation with $50 \mathrm{mg} / \mathrm{Kg}$ of dry matter copper. The cattle showed clinical signs characterized by anorexia, motor incoordination, loss of balance, jaundice, brownish or black urine, diarrhea and death, or were found dead, 10 to 302 days after consumption. Of the 35 cattle that died, 20 underwent necropsy, whose frequent findings were jaundice, enlarged liver with evident lobular pattern, black kidneys, and urinary bladder with brownish to blackish content. Microscopically, the liver showed vacuolar degeneration and/or zonal hepatocellular centrilobular or paracentral coagulative necrosis, in addition to cholestasis, mild periacinal fibrosis, apoptotic bodies, and mild to moderate mononuclear inflammation. Degeneration and necrosis of the tubular epithelium and intratubular hemoglobin cylinders were observed in the kidneys. Copper levels in the liver and kidneys ranged from 5,901.24 to 28,373.14 $\mu \mathrm{mol} /$ $\mathrm{kg}$ and from 303.72 to $14,021 \mu \mathrm{mol} / \mathrm{kg}$, respectively. In conclusion, copper poisoning due to excessive nutritional supplementation is an important cause of jaundice, hemoglobinuria, and death in semi-confined cattle.
\end{abstract}

INDEX TERMS: Copper poisoning, beef cattle, Mato Grosso, Brazil, semi-confinement, mineral supplementation, cattle diseases, trace elements, jaundice.

\begin{abstract}
RESUMO.- [Intoxicação crônica por cobre em bovinos de corte no Estado de Mato Grosso, Brasil.] Cobre é um micromineral essencial, que quando em excesso induz necrose hepática, crise hemolítica, nefrose hemoglobínurica e morte em bovinos. As intoxicações, apesar de incomuns nessa espécie, ocorrem devido a suplementação exacerbada de cobre, pela deficiência de microminerais antagonistas ou secundária a lesão
\end{abstract}

\footnotetext{
${ }^{1}$ Received on February 13, 2020

Accepted for publication on June 23, 2020.

${ }^{2}$ Faculdade de Medicina Veterinária, Universidade de Cuiabá (UNIC), Av. Manoel José de Arruda 3100, Jardim Europa, Cuiabá, MT 78065-900, Brazil.

${ }^{3}$ Faculdade de Medicina Veterinária (FAVET), Universidade Federal de Mato Grosso (UFMT), Av. Fernando Corrêa da Costa 2367, Boa Esperança, Cuiabá, MT 78060-900, Brazil.*Corresponding author: moleta@gmail.com

${ }^{4}$ Veterinarian, Rondonópolis, MT, Brazil.
}

hepática prévia. Relata-se um surto de intoxicação crônica por cobre em bovinos semiconfinados após suplementação com $50 \mathrm{mg} / \mathrm{kg}$ de cobre em matéria seca. Os bovinos manifestaram sinais clínicos caracterizados por anorexia, incoordenação motora, perda de equilíbrio, icterícia, urina acastanhada ou negra, diarreia e morte ou foram encontrados mortos, após 10 a 302 dias do início de consumo. De 35 bovinos que morreram 20 foram submetidos à necropsia sendo achada frequente icterícia, fígado aumentado e com padrão lobular evidente, rins pretos e bexiga urinária repleta de conteúdo acastanhado a enegrecida. Microscopicamente, no fígado havia degeneração vacuolar e ou necrose coagulativa hepatocelular zonal, centrolobular ou paracentral, além de degeneração vacuolar com corpúsculos de Councilman, colestase, fibrose periascinar leve, e inflamação de discreta a moderada. Nos 
rins havia degeneração e necrose do epitélio tubular assim como cilindros de hemoglobina intratubulares. Os níveis de cobre no fígado e rim foram de $5.901,24$ a $28.373,14 \mu \mathrm{mol} / \mathrm{kg}$ e 303,72 a 14.021 $\mu \mathrm{mol} / \mathrm{kg}$ respectivamente. A suplementação nutricional excessiva com cobre pode causar doença hemolítica com icterícia, hemoglobinúria e morte de bovinos mantidos em sistema de semiconfinamento.

TERMOS DE INDEXAÇÃO: Intoxicação por cobre, bovinos de corte, Mato Grosso, Brasil, semiconfinamento, suplementação mineral, doenças de bovinos, oligoelementos, icterícia.

\section{INTRODUCTION}

Copper is an essential trace element that participates in biological processes. These processes include the activity of enzymes involved in cellular respiration, inactivation of free radicals, neurotransmission, connective tissue synthesis, production of pigments, iron cellular metabolism, and hemoglobin formation (Underwood \& Suttle 1999, Festa \& Thiele 2011).

Because of its extensive functionality and the finding of cases of deficiency in cattle in Brazil, copper has been widely used in mineral supplements (Malafaia et al. 2014). Supplementation, added to the levels of copper present in pastures and water, should contribute to cattle reaching the daily copper requirement of 4-8 $\mathrm{mg} / \mathrm{kg}$ of dry matter (DM) (Suttle 2010). After ingestion, copper is absorbed by enterocytes in the small intestine, accesses the portal circulation, binds to albumin and transcuprein, and is then taken to the liver and stored in hepatocytes (Suttle 2010). Homeostasis maintenance between the accumulation of hepatic copper and bile excretion occurs through copper-dependent metalloenzymes such as ceruloplasmin and metallothionein (Rosa \& Mattioli 2002, Tapia et al. 2004). In ruminants, this metabolism is influenced by the absorption and storage capacities of individuals, which differ according to race, animal category, and antagonism with other microminerals (Blanco-Penedo et al. 2006, Cuttance et al. 2018).

In general, cattle tolerate up to $5 \mathrm{~g}$ of dietary copper sulfate per day - a value considered to be higher than the daily needs (Tokarnia et al. 2010). However, when the storage capacity of the hepatocytes is exceeded, the free micromineral becomes toxic because of its potential oxidative effect (García-Vaquero et al. 2012, López-Alonso et al. 2017), and it causes hepatocellular degeneration and necrosis, hemolysis, and hemoglobinuric nephrosis (Cullen \& Stalker 2016). The induction of these lesions is classified as acute when a large amount of copper is exposed in a short period, and this form is associated with cupric parenteral supplementation in calves (Mylrea \& Byrne 1974, Sullivan et al. 1991, Hamar et al. 1997). In contrast, the chronic form is related to constant excessive mineral supplementation (López-Alonso et al. 2000, Hunter et al. 2013, Newcomer et al. 2016). After a subclinical period (weeks to months), cattle present acute manifestations that range from characteristic clinical signs, such as hemoglobinuria, jaundice, mild diarrhea and oliguria, to nonspecific signs such as apathy, dehydration, and weight loss (Minervino et al. 2009, Johnston et al. 2014).

Despite the intense livestock activity in Brazil (IBGE 2017), analysis of surveys addressing the causes of bovine mortality in different regions of the country from 1964 to 2014 showed no reports of deaths due to excessive copper supplementation in cattle (Lucena et al. 2010, Souza et al. 2015, Rondelli et al. 2017), except for one description by
Tokarnia et al. (2000). Conversely, spontaneous cases of copper poisoning have been reported in Europe and Oceania in intensive dairy and beef cattle breeding, which suggests that confined cattle that receive nutritional supplementation with copper are part of a category susceptible to poisoning (López-Alonso et al. 2000, Bidewell et al. 2012, Hunter et al. 2013, Johnston et al. 2014, Kendall et al. 2015). This study aimed to report an outbreak of chronic poisoning caused by excessive copper supplementation in semi-confined cattle in the state of Mato Grosso, Brazil.

\section{MATERIALS AND METHODS}

Epidemiological investigation and clinical examination. This study was carried out on a farm that raises beef cattle under semi-confinement management located in the municipality of Rondonópolis, state of Mato Grosso, Brazil. Information was obtained through interviews with the owner, veterinarian and employees of the property and during visits made by technicians from the Veterinary Pathology Laboratory of Federal University of Mato Grosso (LPVUFMT), Cuiabá Campus, who carried out surveys on the herd and housing areas. All paddocks in the property were inspected, and a clinical inspection of the herd was also performed.

Biochemical and molecular analysis. For biochemical analyses, blood samples of ten bovines were collected through venipuncture. The samples were placed in sterile tubes without EDTA. Biochemical tests were performed using a Wiener Lab CM-200 automatic biochemistry and turbidimetry analyzer.

Three blood samples from different cattle with clinical signs were also collected into a Vacuette ${ }^{\circledR} 6 \mathrm{ml}$ tube without additive for serum copper measurement. The samples were analyzed at the Hermes Pardini Laboratory (Belo Horizonte/MG) by flame atomic absorption spectrophotometry (in-house method).

Blood smears from 20 cattle and spleen and liver impression smears from three cattle were made during necropsy and evaluated, after rapid panoptic staining, to investigate hemiparasites (Bain 2016).

Polymerase chain reaction (PCR) was used to detect Ehrlichia spp. and Babesia spp.. The tests were carried out at the Virology and Rickettsiosis Laboratory of UFMT (LVR-UFMT), Cuiabá campus, using a BIO-RAD T100 ${ }^{\mathrm{TM}}$ thermocycler, and the images of the gels were captured and processed in a photo-documentation system (ChemiDoc XRS+, Bio-Rad) (Almeida et al. 2012).

Necropsy and histopathological examination. Twenty cattle were submitted to necropsy, nine of which showed clinical signs and died spontaneously, two were euthanized, and nine were found dead. Morphological changes were noted and photographic records were taken. Fragments of the organs of these animals were collected, fixed in $10 \%$ formalin, identified in sequence from B1 to B20, and sent to the LPV-UFMT (Table 1 ).

Seventeen samples from cattle submitted to necropsy by the property's veterinarian are identified in sequence from B1 to B7 and B11 to B20. Samples B1 to B7 were received between May 10, 2018 and May 23, 2018. Samples B11 to B20 were from cattle that died between May 27, 2018 and July 5, 2018. Three cattle, B8, B9 and B10, presenting clinical alterations, were collected between May 24 and 26, 2018 and submitted to necropsy by the LPV_UFMT team. Fragments of the organs received were cleaved, routinely processed, embedded in paraffin, and stained with hematoxylin and eosin (HE). Sections of the liver from a bovine were subjected to the Von Kossa histological technique (calcium). Liver and kidney fragments from all 20 cattle were subjected to histochemical staining with rubeanic acid for copper detection. 
Analysis of feed and pasture, chemical analysis of soil, and evaluation of levels of copper (Cu), molybdenum (Mo) and sulfur (S) in offal. Pasture and soil samples were collected in two paddocks where animal deaths occurred. These were identified and sent to "Agroanálise Laboratórios Integrados" (Cuiabá/MT) to determine copper and sulfur levels by atomic absorption spectrophotometry.

Liver and kidney fragments, conserved in $10 \%$ buffered formalin solution, were sent to the Institute of Biosciences, Ecology Center of the "Federal University of Rio Grande do Sul (UFRGS) for sulfur, copper and molybdenum determination. These samples were analyzed by Atomic Absorption/ Air-Acetylene Flame spectrophotometry and microwave-assisted nitric acid digestion (EPA 3052).

\section{RESULTS}

\section{Epidemiological investigation and clinical signs}

The property contains 700 ha of pasture formed with Brachiaria brizantha, Ipyporã cultivar, and Panicum maximum, Mombaça and Massai cultivars, divided into 40 paddocks. The deaths occurred in seven different paddocks, and four of them were fertilized with monobasic phosphate, ammonium sulfate, potassium chloride, and limestone in December 2017. In January 2018, the farm hosted 3218 cattle under semiconfinement management, with daily consumption estimated at $1.56 \%$ of the diet's live weight with a high roughage to concentrate ratio. Concentrate consumption was estimated at $8.3 \mathrm{~kg}$ of DM/head/day for animals with average weight of $530 \mathrm{~kg}$, with observed weight gain of $1.5-1.8 \mathrm{~kg} / \mathrm{animal} /$ day.

In December 2017, some cattle from different paddocks presented neurological clinical signs and died. The presumed diagnosis, without morphological confirmation, was polioencephalomalacia. After this event, the formulation of the feed used on the property was changed in order to antagonize sulfur absorption and prevent copper deficiency. At the beginning of January 2018, copper was added to the feed $\mathrm{mix}$, with an increase from 20 to $50 \mathrm{mg} / \mathrm{kg}$ of DM. The levels of S, Mo, and total iron (Fe) were not significantly changed.

From January 10, 2018 to July 5, 2018, 35 Nelore cattle, with predominance of males aged 18-36 months, died on this farm. However, 15 deaths occurred before April 20, when detailed clinical inspections or collections for complementary exams of these cattle began. In January 2018, herders found six $(6 / 15)$ dead cattle during paddock inspection. Two of these cattle were examined by collaborators, who noticed marked jaundice, increased gallbladder volume, and bladders with brownish to blackish content. Subsequently, the veterinarian at the property reported that nine deaths (9/15) occurred in April 2018 in different paddocks. One of the animals found dead was submitted to necropsy, which showed serous and yellowish fat (jaundice). Samples were not collected for complementary exams.

From April 20 to July 5, 2018, monitoring showed 20 deaths in the property, and the first collection for further exams occurred on May 9, 2018. Nine cattle (9/20) were found dead without any clinical changes. In the other (11/20), clinical signs were noted, ranging from apathy, reluctance to move, and distancing from the herd. Motor incoordination, loss of balance, visual impairment, diarrhea, or dry stools were also observed. Four cattle (4/11) showed jaundice, and in one animal (1/4) presented blackened urine. In May, treatment for bovine parasitic sadness (Terramicina LA ${ }^{\circledR}$, Ganaseg ${ }^{\circledR}$, Borgal $^{\circledR}$, and Mercepton ${ }^{\circledR}$ ) was started in three cattle, and no clinical response was observed.

Table 1. Identification of samples and gross characteristics of cattle with chronic copper poisoning in the municipality of Rondonópolis/MT from April to July 2018

\begin{tabular}{|c|c|c|c|c|c|c|c|c|c|}
\hline \multirow[b]{2}{*}{ Bovine } & \multirow{2}{*}{$\begin{array}{c}\text { Age } \\
\text { (months) }\end{array}$} & \multirow[b]{2}{*}{ Sex } & \multirow[b]{2}{*}{ Breed } & \multirow{2}{*}{$\begin{array}{l}\text { Feed intake time (days) } \\
50 \mathrm{mg} \text { copper/kg/DM }\end{array}$} & \multicolumn{5}{|c|}{ Major gross changes } \\
\hline & & & & & Jaundice & Liver volume & $\begin{array}{l}\text { Disclosure of the } \\
\text { lobular pattern }\end{array}$ & Urine color & Kidney color \\
\hline B1 & 24 & $M$ & Nelore & 282 & ++ & + & $\mathrm{N}$ & $\mathrm{AC}$ & $\mathrm{E}$ \\
\hline B2 & 24 & M & Nelore & 198 & +++ & + & $* *$ & $\mathrm{AC}$ & - \\
\hline B3 & 18 & M & Nelore & 99 & + & NA & +++ & $\mathrm{AC}$ & $\mathrm{N}$ \\
\hline B4 & 24 & M & Nelore & 205 & - & - & - & - & - \\
\hline B5 & 24 & M & Nelore & 201 & +++ & ++ & $\mathrm{N}$ & $\mathrm{AC}$ & $\mathrm{E}$ \\
\hline B6 & 24 & M & Nelore & 212 & ++ & ++ & + & $\mathrm{AC}$ & $\mathrm{E}$ \\
\hline B7 & 18 & M & Nelore & 106 & + & NA & +++ & $\mathrm{N}$ & $\mathrm{P}$ \\
\hline B8 & 24 & M & Nelore & 302 & +++ & ++ & - & $\mathrm{AC}$ & $\mathrm{E}$ \\
\hline B9 & 24 & M & Nelore & 216 & NA & NA & $\mathrm{N}$ & $\mathrm{N}$ & $\mathrm{P}$ \\
\hline B10 & 36 & M & Nelore & 290 & +++ & ++ & + & $\mathrm{AC}$ & $\mathrm{E}$ \\
\hline B11 & 24 & M & Nelore & 110 & +++ & ++ & + & $\mathrm{AC}$ & $\mathrm{E}$ \\
\hline B12 & 24 & M & Nelore & 117 & NA & NA & - & - & - \\
\hline B13 & 24 & M & Nelore & 232 & ++ & NA & A & $\mathrm{AC}$ & $\mathrm{E}$ \\
\hline B14 & 36 & $\mathrm{~F}$ & Crossbred & 297 & NA & NA & $\mathrm{N}$ & - & $\mathrm{P}$ \\
\hline B15 & 24 & M & Nelore & 211 & +++ & +++ & + & $\mathrm{AC}$ & $\mathrm{E}$ \\
\hline B16 & 24 & M & Nelore & 208 & +++ & +++ & ++ & $\mathrm{AC}$ & $\mathrm{E}$ \\
\hline B17 & 18 & M & Nelore & 76 & NA & ++ & +++ & $\mathrm{N}$ & $\mathrm{N}$ \\
\hline B18 & 24 & M & Nelore & 100 & + & + & ++ & $\mathrm{N}$ & $\mathrm{P}$ \\
\hline B19 & 36 & M & Crossbred & 297 & +++ & ++ & +++ & $\mathrm{CC}$ & $\mathrm{E}$ \\
\hline B20 & 24 & $\mathrm{M}$ & Nelore & 211 & +++ & +++ & ++ & $\mathrm{CC}$ & $\mathrm{E}$ \\
\hline
\end{tabular}

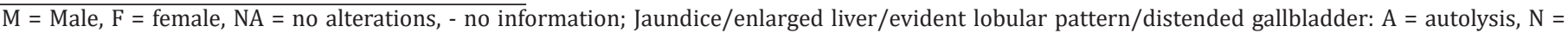

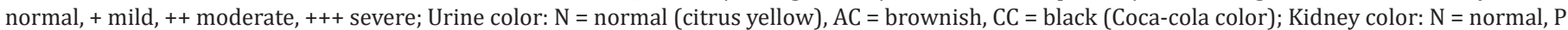
$=$ pale, $\mathrm{E}=$ blackish (metallic black). 
In addition, in May, given the suspicion of chronic copper poisoning, it was recommended that this micromineral be suppressed in the feed. Cu level was adjusted from 50 to 20 $\mathrm{mg} / \mathrm{kg}$ of DM, and later in that month the level was reduced to $11 \mathrm{mg} / \mathrm{kg}$ of DM, keeping the $\mathrm{S}$ and total Fe values at 0.2 and $17 \mathrm{mg} / \mathrm{kg}$, respectively.

\section{Necropsy findings}

The main gross changes found at necropsy are shown in Table 1 . In one case $(1 / 20)$, no information on gross changes was obtained because collection was carried out by the farm employees. In cases which these findings were described, gross changes were similar, with variation in intensity and/ or presence of jaundice (15/19), enlarged and brownish liver $(13 / 19)$ (Fig.1A), and evidence of lobular pattern $(11 / 16)$ (Fig.1B). In four cases, observations were related to the gallbladders, which were all distended, with liquid to pasty to lumpy content ranging from green to brown.

Gross changes were described for kidneys and urinary bladder content in 17 cases. The kidneys were predominantly black (11/17) (Fig.1C), pale (Fig.1D) (4/17), or had a normal color (2/17). Urine color was brownish (11/17), blackish (2/17), or normal (citrus yellow) (4/17).

In the thoracic cavity of B19, petechiae and ecchymosis were observed in the parietal pleura. B20 showed multifocal, irregular, brownish, $3 \mathrm{~cm}$ diameter areas in the myocardium. In B10, the mucosa of the omasum and small intestine had multifocal ulcers, whereas ulcers in the abomasum and rectum were red.

\section{Histopathological results}

Nineteen of the 20 liver and kidney samples presented morphological changes, and one was excluded from the evaluation due to marked postmortem changes. The main histopathological alterations observed in all livers (Table 2) were zonal coagulative necrosis (15/19) and/or hepatocellular vacuolar degeneration (14/19). Centrilobular necrosis associated with congestion and hemorrhage (Fig.2A) was seen in 13 cases (13/15), two (2/13) of which occasionally had a paracentral pattern, and four (4/13) extended to the mediozonal region. Necrosis was massive in two cases $(2 / 15)$. Individual hepatocyte necrosis was present in 12 cases $(12 / 19)$
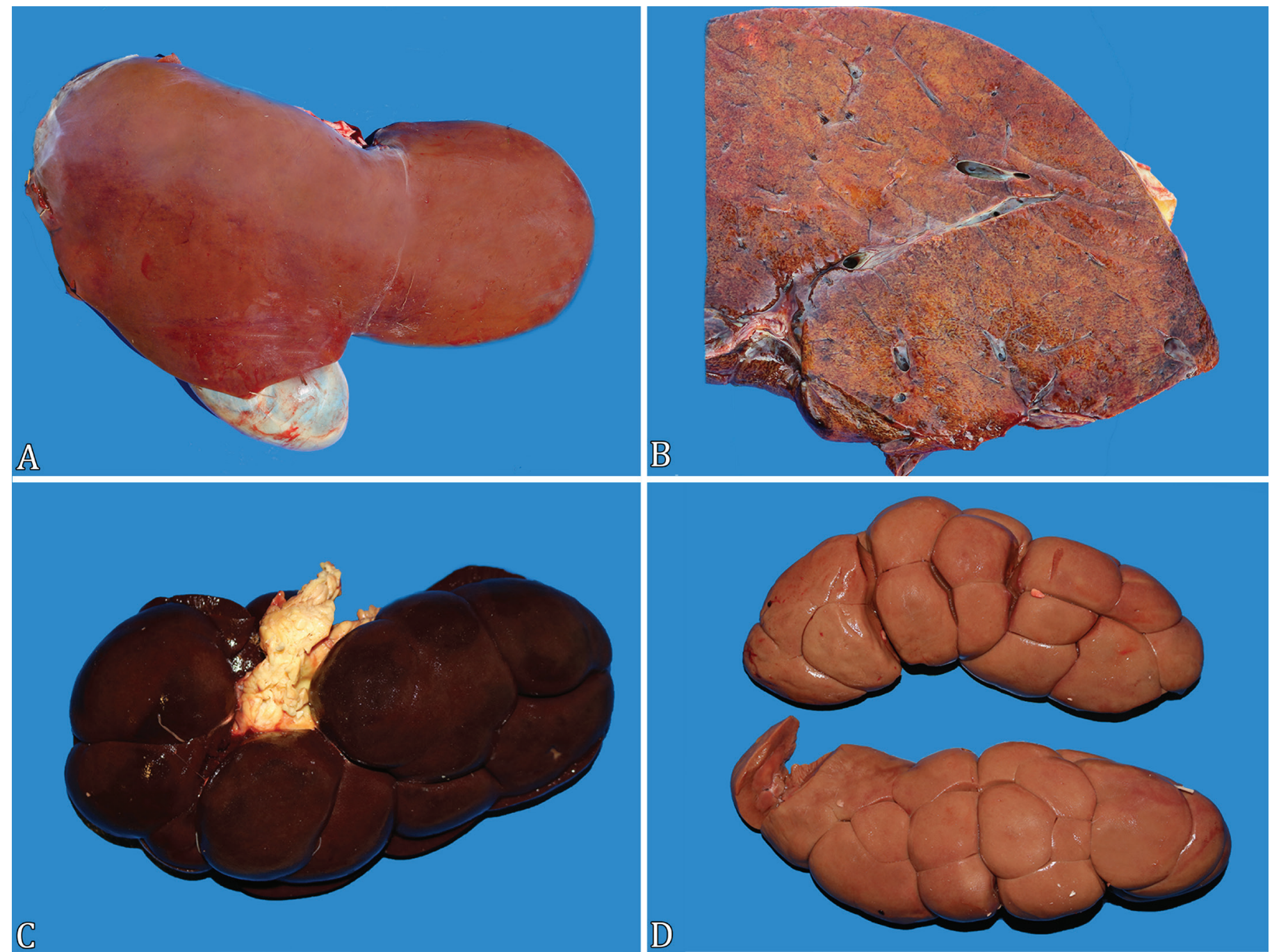

Fig.1. Gross findings in liver and kidney of cattle chronically poisoned by copper. (A) Liver with swelling and brownish capsular surface $(13,171 \mu \mathrm{mol} / \mathrm{kg}$ of Cu) (B18). (B) On the cut surface, an evident lobular pattern (28,373 $\mu \mathrm{mol} / \mathrm{kg}$ of Cu) is observed (B19). (C) Diffuse and moderately blackened kidney $(13,391 \mu \mathrm{mol} / \mathrm{kg}$ of $\mathrm{Cu})$ (B16). (D) Kidney with diffuse and moderate pallor $(8,639 \mu \mathrm{mol} / \mathrm{kg}$ of Cu) (B17). 
and were associated with degenerative changes and in areas adjacent to zonal necrosis $(7 / 12)$, or were noted in cases where hepatocellular degeneration predominated (4/12), or only associated with the limits of areas where there was zonal necrosis $(1 / 12)$.

Hepatocellular degeneration (14/19), predominantly periacinal (8/14), was classified as macrovesicular $(7 / 8)$ or microvesicular (1/8). Less frequently, massive (Fig. 2B) (4/14) and centrilobular (2/14) degeneration was also observed. Proliferation of the periportal fibrous connective tissue was found in 11 samples, seven considered discrete (7/11) and four moderate (4/11). Cholestasis was present in 12 cases, six of which were mild (6/12), three moderate (3/12), and three severe (3/12). Councilman's bodies were observed in nine cases. Finally, a mild inflammatory infiltrate, adjacent to necrosis, was observed in 15 cases, 13 (13/15) neutrophilic and two (2/15) mixed.

The main renal changes (Table 3 ) observed in 20 cattle submitted to necropsy were coagulative necrosis and vacuolar degeneration of the tubular epithelium (Fig.2C). Tubular coagulative necrosis prevailed in nine cases (9/19), tubular degeneration was found in three cases $(3 / 19)$, and they occurred with the same intensity in seven cases $(7 / 19)$. Hemoglobin cylinders in the tubular lumen were verified in 14 cases (Fig.2D) (14/19). Mild to moderate glomerulonephritis was identified in nine animals. Mild to moderate interstitial inflammation was found in 11 kidneys, and interstitial fibrosis was present in four samples, three moderate and one mild.

Findings in other organs included mild vacuolization of the white matter of the brain in B2, occasional coagulative necrosis of cardiomyocytes in the myocardium in B20, and multifocal necrotizing omasitis and enterocolitis in B10.
The rubeanic acid technique was performed on all 20 samples. A positive, green to blackish, mild to moderate, intracytoplasmic marking in hepatocytes was observed in 17 samples and in the epithelium or renal tubular lumen in eight samples.

\section{$\mathrm{Cu}, \mathrm{S}$ and Mo in liver and kidney and serum $\mathrm{Cu}$}

Copper levels in the liver and kidneys ranged from 5,901.24 to $28,373.14 \mu \mathrm{mol} / \mathrm{kg}$ and from 303.72 to $14,021 \mu \mathrm{mol} / \mathrm{kg}$, respectively. Of the three animals analyzed, $\mathrm{S}$ levels ranged from 52.55 to $217.97 \mu \mathrm{mol} / \mathrm{kg}$, whereas Mo levels varied between 0.019476 and $0.45284 \mu \mathrm{mol} / \mathrm{kg}$. In blood serum, Cu levels ranged from 116 to $350 \mathrm{mcg} / \mathrm{dL}$ (Table 4).

\section{Biochemical and molecular analyses}

The serum activities of liver enzymes that indicate injuries, such as Glutamic-Oxaloacetic Transaminase (GOT) and Glutamic-Pyruvic Transaminase (GPT), were above the reference values (Table 5) in seven animals (7/7) and only GPT in six (6/7). Creatinine was measured in seven animals, with six $(6 / 7)$ values overlapping the reference. In the 20 blood smears, there were no morphological structures compatible with Babesia spp. or Anaplasma spp. Serum samples from animals B10, B18, and B19 were negative for Ehrlichia spp. and Babesia spp.

\section{Pasture and soil analyses for $\mathrm{Cu}$, Mo, and $\mathrm{S}$ levels}

Mean copper values in the pastures varied between 6.7 (Panicum maximum var. Mombaça) and $6.5 \mathrm{mg} / \mathrm{kg}$ (Brachiaria brizantha). Sulfur values averaged $1.2 \mathrm{mg} / \mathrm{kg}$ in both pastures (Panicum maximum var. Mombaça and Brachiraria brizantha). In the soil, the mean levels of $\mathrm{Cu}$ and $\mathrm{S}$ were 0.25 and 29.1 $\mathrm{mg} / \mathrm{dm}^{3}$, respectively.

Table 2. Histopathological characteristics of cattle livers with chronic copper poisoning

\begin{tabular}{|c|c|c|c|c|c|c|c|c|c|c|}
\hline Bovine & $\begin{array}{c}\text { Centrilobular } \\
\text { necrosis }\end{array}$ & $\begin{array}{l}\text { Massive } \\
\text { necrosis }\end{array}$ & $\begin{array}{l}\text { Individual } \\
\text { necrosis }\end{array}$ & $\begin{array}{l}\text { Centrilobular } \\
\text { degeneration }\end{array}$ & $\begin{array}{c}\text { Periacinal } \\
\text { degeneration }\end{array}$ & $\begin{array}{c}\text { Massive } \\
\text { degeneration }\end{array}$ & Fibrosis & Cholestasis & $\begin{array}{l}\text { Councilman } \\
\text { body }\end{array}$ & Inflammation \\
\hline B1 & +++ & - & - & - & $++\mathrm{Ma}$ & - & - & - & + & $+\mathrm{N}$ \\
\hline B2 & $+++^{*}$ & - & - & - & $+\mathrm{Ma}$ & - & + & + & - & $+\mathrm{N}$ \\
\hline B3 & +++ & - & - & & $+\mathrm{Ma}$ & - & - & - & - & - \\
\hline B4 & - & - & + & $+\mathrm{Mi}$ & - & - & - & - & - & - \\
\hline B5 & - & - & ++ & - & - & $+++\mathrm{Ma}$ & ++ & + & + & - \\
\hline B6 & $++* *$ & - & ++ & - & - & $+++\mathrm{Ma}$ & & +++ & - & $+\mathrm{N}$ \\
\hline B7 & +++ & - & - & - & - & - & ++ & - & - & $+\mathrm{N}$ \\
\hline B8 & $++* *$ & - & - & - & - & - & + & + & - & $+\mathrm{N}$ \\
\hline B9 & - & +++ & - & - & - & - & - & ++ & - & $++\mathrm{N}$ \\
\hline B10 & $++^{*}$ & - & + & - & - & $+++\mathrm{Ma}$ & + & +++ & + & $+\mathrm{N}$ \\
\hline B11 & $++* *$ & - & + & - & - & - & + & + & - & $+\mathrm{N}$ \\
\hline B12 & +++ & - & + & - & $+\mathrm{Ma}$ & - & - & - & + & $+\mathrm{N}$ \\
\hline B13 & A & A & A & A & A & A & A & A & A & A \\
\hline B14 & $+++* *$ & - & + & - & $++\mathrm{Ma}$ & - & + & + & - & $++\mathrm{M}$ \\
\hline B15 & - & - & +++ & - & - & $+++\mathrm{Ma}$ & ++ & ++ & ++ & $+\mathrm{N}$ \\
\hline B16 & +++ & - & + & - & $++\mathrm{Ma}$ & - & ++ & +++ & + & $+\mathrm{M}$ \\
\hline B17 & - & +++ & - & - & - & - & - & - & - & $++\mathrm{M}$ \\
\hline B18 & +++ & - & + & - & $++\mathrm{Mi}$ & - & + & + & + & $+\mathrm{N}$ \\
\hline B19 & - & - & + & $++\mathrm{Mi}$ & - & - & - & - & + & - \\
\hline B20 & ++ & - & + & - & $+\mathrm{Ma}$ & - & + & ++ & + & $+\mathrm{N}$ \\
\hline
\end{tabular}



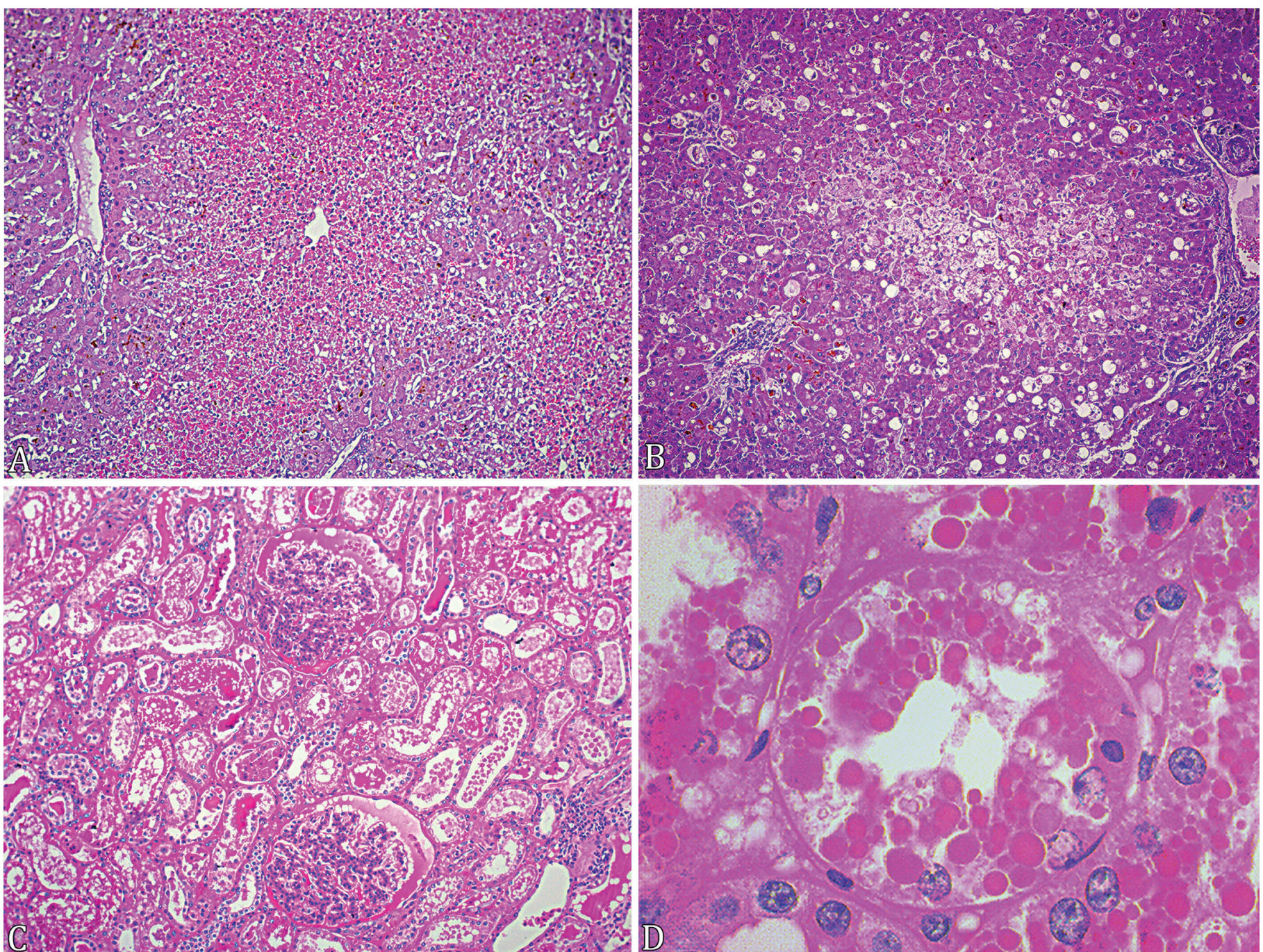

Fig.2. Histopathological findings of liver and kidney of cattle chronically poisoned by copper. (A) Centrilobular coagulative hepatocellular necrosis associated with congestion and hemorrhage. HE, obj.10x. (B) Hepatocellular, macrovesicular, massive degeneration associated with centrilobular necrosis and cholestasis. HE, obj.10x. (C) Kidney with multifocal areas of tubular epithelial degeneration and necrosis. In the tubular light and the Bowman space, there is amorphous and strongly eosinophilic material compatible with hemoglobin. HE, obj.10x. (D) There is hyaline globular material (hemoglobin) in greater magnitude in addition to cytoplasmolysis, karyorrhexis and nuclear pycnosis. HE, obj.100x.

\section{DISCUSSION}

The epidemiological, clinical and pathological aspects and the serum, hepatic and renal $\mathrm{Cu}$ values found in the described outbreak are consistent with chronic copper poisoning in cattle associated with excessive mineral supplementation. Copper poisoning was first investigated in Australian cattle in the 1940s (Dick \& Bull 1945). From that period to the present day, cases have been reported in several countries. They are often associated with parenteral or nutritional supplementation in dairy cattle herds under intensive nutritional management (Galey et al. 1991, Bradley 1993, Steffen et al. 1997, Bidewell et al. 2012, Johnston et al. 2014). In contrast to the aforementioned description, cases of spontaneous $\mathrm{Cu}$ poisoning are rare in Brazil, with only one report of deaths in beef cattle after feeding with chicken litter (Tokarnia et al. 2000 ), and there are no reports on natural occurrence of $\mathrm{Cu}$ poisoning in beef cattle due to excessive supplementation.
In the present case, $\mathrm{Cu}$ supplementation per $\mathrm{kg}$ of $\mathrm{DM}$ was increased from 20 to $50 \mathrm{mg} / \mathrm{kg}$. Considering the last value and the daily consumption per bovine of approximately $8.3 \mathrm{~kg}$ of concentrate, each animal ingested an average of $415 \mathrm{mg} \mathrm{Cu} / \mathrm{day}$, which represents a surplus of $352 \mathrm{mg}$ of $\mathrm{Cu}$ when considering the required value of $63.28 \mathrm{mg}$ for maintenance and weight gain of male Zebu cattle (Silva et al. 2016). It is also verified that the value of $50 \mathrm{mg} \mathrm{Cu} / \mathrm{kg}$ DM represents $20 \mathrm{mg} \mathrm{Cu} / \mathrm{kg}$ DM in excess to the maximum limit established as safe by the European Union (EU) Commission Implementing Regulation in 2018. The EU regulation made this determination after observing that regular diets with excessive values caused poisoning (Bidewell et al. 2012, Kendall et al. 2015, Sinclair \& Atkins 2015). It is believed that the gradual change of the Brazilian livestock breeding system, specifically in the state of Mato Grosso, to confinement or semi-confinement systems (IMEA 2019) allows cases of poisoning to occur due to the use of exaggerated amounts of $\mathrm{Cu}$ in nutrition. 
Table 3. Histopathological characteristics of cattle kidneys with chronic copper poisoning

\begin{tabular}{|c|c|c|c|c|c|c|}
\hline Bovine & Tubular necrosis & $\begin{array}{c}\text { Tubular } \\
\text { degeneration }\end{array}$ & $\begin{array}{c}\text { Hemoglobin } \\
\text { cylinder }\end{array}$ & Glomerulonephritis & Fibrosis & Inflammation \\
\hline B1 & +++ & - & ++ & $++\mathrm{P}$ & - & $+\mathrm{NS}$ \\
\hline B2 & ++ & +++ & +++ & $+\mathrm{MP}$ & - & $+\mathrm{NS}$ \\
\hline B3 & ++ & +++ & +++ & $++\mathrm{MP}$ & - & - \\
\hline B4 & - & - & - & - & ++ & - \\
\hline B5 & ++ & ++ & ++ & $+\mathrm{P}$ & - & $+\mathrm{M}$ \\
\hline B6 & ++ & + & + & - & - & - \\
\hline B7 & ++ & - & - & - & - & - \\
\hline B8 & +++ & + & ++ & $+\mathrm{P}$ & - & $++\mathrm{NS}$ \\
\hline B9 & ++ & + & - & $++\mathrm{MP}$ & ++ & - \\
\hline B10 & + & +++ & +++ & $++\mathrm{P}$ & ++ & - \\
\hline B11 & ++ & ++ & +++ & $+\mathrm{P}$ & - & - \\
\hline B12 & ++ & + & + & $++\mathrm{MP}$ & - & - \\
\hline B13 & A & A & ++ & A & - & $+\mathrm{NS}$ \\
\hline B14 & ++ & + & ++ & - & - & $+\mathrm{NS}$ \\
\hline B15 & ++ & ++ & +++ & - & - & $+\mathrm{NS}$ \\
\hline B16 & ++ & + & +++ & - & - & $+\mathrm{NS}$ \\
\hline B17 & + & + & - & - & - & - \\
\hline B18 & + & + & - & - & - & $+\mathrm{NS}$ \\
\hline B19 & - & + & - & - & - & $+\mathrm{NS}$ \\
\hline B20 & +++ & ++ & +++ & - & + & $+\mathrm{M}$ \\
\hline
\end{tabular}

P Proliferative, MP membranoproliferative, NS nonsuppurative, M mixed; A = autolysis.

Table 4. Levels of copper, sulfur, molybdenum in the liver, kidney and serum of cattle with chronic copper poisoning

\begin{tabular}{|c|c|c|c|c|c|}
\hline \multirow[b]{2}{*}{ Bovine } & \multicolumn{3}{|c|}{ Liver } & \multirow{2}{*}{$\begin{array}{c}\text { Kidney } \\
\text { Copper } \\
(\mu \mathrm{mol} / \mathrm{kg}) \\
\end{array}$} & \multirow{2}{*}{$\begin{array}{c}\text { Blood serum } \\
\text { Copper }(\mathrm{mcg} / \mathrm{dL})\end{array}$} \\
\hline & $\begin{array}{c}\text { Copper } \\
(\mu \mathrm{mol} / \mathrm{kg})\end{array}$ & $\begin{array}{c}\text { Molybdenum } \\
(\mu \mathrm{mol} / \mathrm{kg})\end{array}$ & $\begin{array}{c}\begin{array}{c}\text { Sulfur } \\
(\mu \mathrm{mol} / \mathrm{kg})\end{array} \\
\end{array}$ & & \\
\hline B2 & 10.606 & - & - & - & - \\
\hline B3 & 5.901 & - & & 1.410 & - \\
\hline B5 & 10.417 & - & - & - & - \\
\hline B6 & 20.552 & - & & 634 & 116 \\
\hline B7 & 18.805 & - & & 14.021 & - \\
\hline B8 & 8.293 & - & - & 511 & - \\
\hline B9 & 9.536 & - & - & 6.168 & - \\
\hline B10 & 7.836 & - & & 321 & 192 \\
\hline B16 & 13.391 & 0,044 & 217,97 & 303 & - \\
\hline B17 & 8.639 & - & - & - & - \\
\hline B18 & 13.171 & - & - & 7.427 & - \\
\hline B19 & 28.373 & 0,019 & 52,55 & 428 & 350 \\
\hline B20 & 9.992 & 0,045 & 176,38 & 6.341 & 350 \\
\hline Reference values & ->8.000 $\mu \mathrm{mol} / \mathrm{kg}^{*}$ & $0,191-0,383^{* * *}$ & $900-3.000^{* * * *}$ & $600-800 \mu \mathrm{mol} / \mathrm{kg} * *$ & $19-38 \mathrm{mcg} / \mathrm{dl}^{* *}$ \\
\hline
\end{tabular}

Table 5. Serum activity of liver and kidney enzymes of cattle with chronic copper poisoning

\begin{tabular}{|c|c|c|c|c|}
\hline Bovine & GGT (UI/L) & GOT (U/L) & GPT (U/L) & Creatinine $(\mathrm{mg} / \mathrm{dL})$ \\
\hline B3 & 30.09 & - & - & 2.2 \\
\hline B6 & - & 633 & 86 & - \\
\hline B14 & - & 3166 & 1190 & 2.9 \\
\hline B17 & - & 5550 & 1520 & 44.3 \\
\hline B18 & - & 182 & 20 & 1.6 \\
\hline Reference values* & $\geq 26$ & 45 to 110 & 7 to 36 & 0.6 to 1.8 \\
\hline
\end{tabular}

GGT = Gamma-glutamyl transferase, GOT = glutamic-oxaloacetic transaminase, GPT = glutamic-pyruvic transaminase; * Minervino et al. (2009). 
In the outbreak described in this study, the reports state that the change in feed formulation, with an increase in $\mathrm{Cu}$ supplementation, was made after the alleged occurrence of polioencephalomalacia assigned to $\mathrm{S}$ excess, and assuming that $S$ excess could cause negative effects related to the formation of thiomolybdates (TM) in the rumen environment (Suttle 1974, Dick et al. 1975). Absorbed TM have an affinity for enzymes and other organic components that contain $\mathrm{Cu}$, causing decreased enzyme activity which, consequently, can induce clinical signs of $\mathrm{Cu}$ deficiency. In ruminants, the signs of $\mathrm{Cu}$ deficiency are nonspecific or subclinical, and include a reduction in weight gain, decreased food consumption or inefficient feed conversion, altered hair pigmentation, and negative impacts on reproduction (Gould \& Kendall 2011). In this occurrence, the effects related to the formation of cupro-thiomolybdates were not evaluated, and only the toxic consequences of $\mathrm{Cu}$ hepatocellular accumulation were observed. The antagonism that other trace elements other than S, such as Mo, Fe and zinc (Zn), have on the absorption and use of $\mathrm{Cu}$ is an essential factor to be considered when planning supplementation (López-Alonso et al. 2017, Sinclair et al. 2017, Skalny et al. 2019). However, the values of these microminerals were not established before changes in the $\mathrm{Cu}$ content were introduced in the feed.

Other less common causes of $\mathrm{Cu}$ poisoning in cattle include ingestion of pastures with normal $\mathrm{Cu}$ content and low in antagonistic microminerals (phytogenic poisoning) (LópezAlonso et al. 2000) or previous liver damage (hepatogenic poisoning) (Newcomer et al. 2016). Phytogenic and hepatogenic poisoning events were ruled out due to the finding of an excessive exogenous $\mathrm{Cu}$ source and the absence of clinical and pathological findings that indicated previous liver damage.

The variation in the clinical course of poisoning was evident when the time of ingestion of the $\mathrm{Cu}$-rich diet, the subsequent manifestation of clinical signs, or eventual death of the cattle were observed. This wide variation can be justified by the distinct individual susceptibility, which is influenced by sex, breed, and age (Littledick et al. 1995, Miranda et al. 2010, López-Alonso et al. 2017). Considering the reports of injuries made by the property's employees, it is believed that death of cattle compatible with $\mathrm{Cu}$ poisoning occurred 10 days after changing the feed formulation to $50 \mathrm{mg}$ of copper/ kg DM. Previous supplementation (20 mg copper/kg DM) possibly contributed to the hepatocellular $\mathrm{Cu}$ deposit and clinical manifestation of hemolysis in a shorter period after the $\mathrm{Cu}$ increase in the diet. However, the values of visceral $\mathrm{Cu}$ deposits were not measured before the onset of mortality.

Regarding the age of the bovines at the time of visceral $\mathrm{Cu}$ accumulation measurements, the three youngest individuals (aged 18 months) to manifest the disease were those that ingested the feed for the shortest time (76-106 days). Speed of hepatic $\mathrm{Cu}$ accumulation in younger animals is favored by the smaller $\mathrm{Cu}$ deposit in the muscles during a period of lower growth rate or when the animals are very young and receive $\mathrm{Cu}$ during lactation (Littledick et al. 1995, Miranda et al. 2010, López-Alonso et al. 2017). Greater breed susceptibility is observed in Holstein compared with Jersey and Angus and with Simental (Gooneratne et al. 1994, Littledick et al. 1995, Miranda et al. 2010). However, there are no studies addressing susceptibility in Nelore to establish comparison.
Of the 20 animals evaluated, nine were found dead without observation of clinical symptoms. This finding can be assigned to the type of management adopted on the farm, high stocking, and once daily inspection of herds, on average, which are facts that allow animals with shorter disease evolution to go unnoticed. This type of occurrence, added to the variation in clinical signs, demonstrate the need for post-mortem examinations and liver $\mathrm{Cu}$ measurements for diagnostic completion (Cullen \& Stalker 2016). In 11 cattle, apathy, reluctance to move, and distancing from the herd were continuously observed. Although unspecific, these findings have been commonly described in cattle poisoned by copper (Galey et al. 1991, Tremblay \& Baird 1991, Bradley 1993, Bidewell et al. 2012, Suttle et al. 2013). Blackened urine related to hemoglobinuria was clinically visualized in one bovine, and jaundice was observed in four cattle. These clinical signs, which are considered classic in Cu poisoning (Tokarnia et al. 2000, Minervino et al. 2009), are not always described in this disease in cattle (Galey et al. 1991, Minervino et al. 2009, Bidewell et al. 2012, Suttle et al. 2013). Minervino et al. (2009), when inducing chronic copper poisoning, obtained in most cattle, in addition to nonspecific clinical signs, a clinical condition considered atypical, such as diarrhea or dry stools, ruminal atony, and oliguria. Changes in the central nervous system, such as motor incoordination, difficulty in moving and visual impairment (Perrin et al. 1990, Bradley 1993), which were also reported in the present outbreak, have already been associated with a condition known as hepatic encephalopathy (Howell et al. 1974, Bidewell et al. 2002).

Increase in serum enzymes that indicate damage to liver or kidney function was constant in the animals evaluated in this study. The increase in transaminases such as GOT and GPT occurs mainly at the stage when hepatocellular necrosis has already been established (Minervino et al. 2009). Serum creatinine is an important marker of renal metabolism (Thrall 2014) and its elevation in these cattle is related to decreased glomerular filtration (Perrone et al. 1992) and hypoxia caused by the intravascular hemolytic crisis (Bozynski et al. 2009, Newman 2013).

Although serum $\mathrm{Cu}$ measurement has been considered insensitive for detection of hepatic $\mathrm{Cu}$ accumulation (LópezAlonso et al. 2006), it can assist with diagnosing poisoning in animals that show clinical signs of the disease (Johnston et al. 2014). In the cattle assessed in this study, values higher the reference were observed in all four sera analyzed (Underwood \& Suttle 1999), and in two (2/4) of these, the serum Cu level was at the upper detection limit of $350 \mathrm{mcg} / \mathrm{dL}$.

The gross findings, characterized by jaundice and blackened urinary bladder content, are consistent with chronic copper poisoning and, in this case, were the most reported postmortem observations. Jaundice was the most frequent observation, and it was related to hepatocellular necrosis and hemolysis (Cullen \& Stalker 2016). The visualization of blackened kidneys in 11 cases showed intravascular hemolysis, even if not clinically verified. Hemolysis occurs as a result of the direct damage that CU does to red blood cells by inducing oxidative stress in the erythrocyte membrane through inhibition of the enzyme glucose-6-phosphate (Fairbanks 1967).

Increased liver volume was a common finding related to excessive hepatocellular $\mathrm{Cu}$ deposit (Cullen \& Stalker 2016). Associated with the event of oxidative stress, it causes 
degenerative and necrotic changes (García-Vaquero et al. 2012), contributing to hepatocellular swelling and increased liver volume (Morgan et al. 2014).

Histopathological evaluation showed predominance of zonal hepatocellular necrosis, with centrilobular necrosis as the most frequent. Similar lesions have already been described in other Cu poisoning events in cattle (Minervino et al. 2009). They are related to the massive release of $\mathrm{Cu}$ and to the acute clinical phase of disease, when intravascular hemolysis occurs (Valli 2007). Hepatocellular degeneration has been associated with the pre-hemolytic phase of disease (Gooneratne et al. 1980). It is related to the gradual accumulation of $\mathrm{Cu}$ in the cytoplasm and nuclei of the hepatocytes (López-Alonso et al. 2017). It can trigger lipid peroxidation of the cell membrane, water accumulation, electrolytes, lipids and formation of autophagic vesicles capable of providing a vacuolar aspect to the cytoplasm (Gooneratne et al. 1980, García-Vaquero et al. 2012, Wang et al. 2014). In those livers, in which hepatocellular degeneration was the most important finding, individual hepatocyte necrosis occurred more frequently. These findings have already been described in other reports of Cu poisoning, but associated with the subclinical phase (Hunter et al. 2013) or the chronic phase of the disease in the absence of a hemolytic crisis (Newcomer et al. 2016). This association was not observed in the present report, since even in the only case (B19) where individual degeneration and necrosis were mild, jaundice and blackened kidneys were evident.

Tubular necrosis was the most frequently observed microscopic renal alteration. It was associated with mild intensity combined with damage to the renal tubular epithelium, caused by the oxidative potential of copper (Zhao et al. 2019). Changes are potentiated by tissue hypoxia (Newman 2013) that occurs during the hemolytic crisis and at the time when excess hemoglobin is present in the renal tubules (Gooneratne et al. 1986).

The histochemical staining of copper, from mild to moderate, did not occur only in liver samples with marked autolysis and putrefaction, but also in two cases where necrosis was massive. Intensity of copper staining in the hepatocyte cytoplasm is experimentally evident until the fifth week of excessive supplementation and decreases as poisoning progresses (Fuentealba et al. 1987). Renal copper staining in these cattle occurred in fewer cases and demonstrated less usefulness in histochemical diagnosis than liver staining (Evering et al. 1990). The smallest evidence of kidney $\mathrm{Cu}$ granules occurs after tubular necrosis that exfoliates cells overloaded with copper to the lumen, which may not be more evident mainly after the beginning of tubular regeneration (Haywood et al. 1985).

Regarding hepatic $\mathrm{Cu}$ levels, Suttle (2010) argues that, given the numerous factors that can individually influence the rate of $\mathrm{Cu}$ absorption, use and storage, a safety range should be used with acceptable values from 6,400 to 16,000 $\mu \mathrm{mol}$ of $\mathrm{Cu} / \mathrm{kg} \mathrm{DM}$. According to Grace \& Knowles (2015), interpretation of the term "adequate" has generated the idea that a more significant $\mathrm{Cu}$ nutritional supply than the necessary can provide greater productive and reproductive gains. In this expectation, excessive supplementation is recommended. However, as in this case, there are reports of deaths associated with chronic copper poisoning, in which the hepatic deposit oscillates between these reference values
(Johnston et al. 2014, Morgan et al. 2014). This information reinforces that $\mathrm{Cu}$ rates in the liver identified as adequate may be present in cattle at risk for developing chronic poisoning. Therefore, the Animal and Plant Health Agency (APHA) of the United Kingdom established that values $>8,000 \mu \mathrm{mol} / \mathrm{g}$ of $\mathrm{Cu}$ DM should be considered toxic, even in the absence of clinical signs (Kendall et al. 2015).

Levels between 600 and $800 \mu \mathrm{mol}$ of $\mathrm{Cu} / \mathrm{kg} \mathrm{DM}$ are considered acceptable in the bovine kidney (Suttle 2010). In this case, chemical analyses of 10 samples of renal tissue revealed high values in six cases and within the normal range in four cases. Typically, urinary copper excretion is low (López-Alonso et al. 2017). Therefore, the interpretation of $\mathrm{Cu}$ evaluation results in this tissue should consider the dynamics between intensity of liver damage (Zischka et al. 2011) and the existing amount of the $\mathrm{Cu}$ carrier protein CTR1 (Han et al. 2009) in each animal (Gray et al. 2012).

\section{CONCLUSIONS}

Nutritional $\mathrm{Cu}$ supplementation for cattle with values from 20 to $50 \mathrm{mg} / \mathrm{kg}$ of DM is potentially toxic. It can cause hepatocellular accumulation of this micromineral and, consequently, risk of degeneration and hepatocellular necrosis, hemolytic crisis, and nephrosis.

Copper poisoning should be considered a differential diagnosis mainly in confined or semi-confined cattle with jaundice and hemoglobinuria.

Conflict of interest statement.- There are no conflicts of interest.

\section{REFERENCES}

Almeida A.B.P.F., Sousa V.R.F., Cruz F.A.C.S., Seabra F.A.C., Dahroug M.A.A., Figueiredo F.B. \& Madeira M.F. 2012. Canine visceral leishmaniasis: seroprevalence and risk factors in Cuiabá, Mato Grosso, Brazil. Rev. Bras. Parasitol. Vet., 21(4): 359-365. <https://dx.doi.org/10.1590/S198429612012005000005>

Bain B.J. 2016. Células sanguíneas, um guia prático. 3 ed. Artmed, Porto Alegre, 437p.

Bidewell C.A. \& Livesey C.T. 2002. Copper poisoning: an emerging disease in dairy cattle. State Vet. J. 12:16-19.

Bidewell C.A., Drew J.R., Payne J.H., Sayers A.R., Higgins R.J. \& Livesey C.T. 2012. Case study of copper poisoning in a British dairy herd. Vet. Rec. 170(18):464-500.<http://dx.doi.org/10.1136/vr.100267><PMid:22562897>

Blanco-Penedo I., Cruz J.M., López-Alonso M., Miranda M., Castillo C., Hernández J. \& Benedito J.L. 2006. Influence of copper status on the accumulation of toxic essential metals in cattle. Environt. Int. 32(7):901-906. <http:// dx.doi.org/10.1016/j.envint.2006.05.012><PMid:16828868>

Bozynski CC., Evans T.J., Kim D.Y., Johnson G.C., Hughes-Hanks J.M., Mitchell W.J., Rottinghaus G.E., Perry J. \& Middleton J.R. 2009. Copper toxicosis with hemolysis and hemoglobinuric nephrosis in three adult Boer goats. J. Vet. Diagn. Invest. 21(3):395-400.<http://dx.doi.org/10.1177/104063870902100319> <PMid:19407099>

Bradley C.H. 1993. Copper poisoning in a dairy herd fed a mineral supplement. Can. Vet. J. 34(5):287-292. <PMid:17424221>

Commission Implementing Regulation (EU). 2018. EU regulation 2018/1039. Official Journal of the European Union. L 186/3-186-24.

Cullen J.M. \& Stalker M.J. 2016. Liver and Biliary System, p.297-388. In: Maxie M.G. (Ed.), Jubb, Kennedy and Palmer's Pathology of Domestic Animals. Vol.2. 6th ed. Elsevier Saunders, Philadelphia. 1219p. <http://dx.doi.org/10.1016/B978-0-7020-5318-4.00008-5> 
Cuttance E.L., Laven R.A. \& Watts A. 2018. Effect of sodium molybdate supplementation on high concentrations of $\mathrm{Cu}$ in liver of yearling bulls. N. Z. Vet. J. 66(4):194-198. <http://dx.doi.org/10.1080/00480169.2018 .1440653><PMid:29446704>

Dias R.S., Lopez S., Montanholi Y.R., Smith B., Haas L.S., Miller S.P. \& France J. 2013. A meta-analysis of the effects of dietary copper, molybdenum, and sulfur on plasma and liver copper, weight gain, and feed conversion in growing-finish cattle. J. Anim. Sci. 91(12):5714-5723. <http://dx.doi. org/10.2527/jas.2013-6195><PMid:24265326>

Dick A.T. \& Bull L.B. 1945. Some preliminary observations on the effect of molybdenum on copper metabolism in herbivorous animals. Aust. Vet. J. 21(3):70-72. <http://dx.doi.org/10.1111/j.1751-0813.1945.tb04462.x> $<$ PMid:21006809>

Dick A.T., Dewey D.W. \& Gawthorne J.M. 1975. Thiomolybdates and the copper-molybdenum-sulphur interaction in ruminant nutrition. J. Agri. Sci. 85(3):567-568. <http://dx.doi.org/10.1017/S0021859600062468>

Evering W.E., Haywood S., Elmes M.E., Jasani B. \& Trafford J. 1990. Histochemical and immunocytochemical evaluation of copper and methallothionein in the liver and kidney of copper loaded rats. J.Pathol. 160(4):305-312. <http://dx.doi.org/10.1002/path.1711600406> <PMid:2358968>

Fairbanks V.F. 1967. Copper sulfate induced hemolytic anemia inhibition of glucose 6 phosphate dehydrogenase and other possible etiologic mechanisms. Arch. Intern. Med.120(4):428-432.<http://dx.doi.org/10.1001/ archinte.120.4.428> <PMid:4293707>

Festa R.A. \& Thiele D.J. 2011. Copper: an essential metal in biology. Curr. Biol. 21(21):R877-R883. <http://dx.doi.org/10.1016/j.cub.2011.09.040> <PMid:22075424>

Fuentealba I.C., Haywood S. \& Trafford J. 1987. Evaluation of histochemical methods for the detection of copper overload in rat liver. Liver. 7(5):277-282. <http://dx.doi.org/10.1111/j.1600-0676.1987.tb00356.x><PMid:2447466>

Galey F. D., Mass J., Tronstad R.J., Woods L.W., Johnson B.J., Littelfield E.S., Wallstrum R. \& Darius L.C. 1991. Copper toxicosis in two herds of beef calves following injection with copper disodium edetate. J. Vet. Diagn. Invest. 3(3):260-263. <http://dx.doi.org/10.1177/104063879100300316> <PMid:1911999>

García-Vaquero M., López-Alonso M. \& Miranda M. 2012. Histochemistry evaluation of the oxidative stress and the antioxidant status in $\mathrm{Cu}-$ supplemented cattle. Animal. 6(9):1435-1443.<http://dx.doi.org/10.1017/ S1751731112000535><PMid:23031516>

Gooneratne S.R., Christensen D.A., Bailey J.V. \& Symonds H.V. 1994. Effects of dietary copper, molybdenum and sulfur on biliary copper and zinc excretion in Simmental and Angus cattle. Can. J. Anim. Sci. 74(2):315-325. $<$ http://dx.doi.org/10.4141/cjas94-043>

Gooneratne S.R., Howell J. \& Cook R.D. 1980. An ultrastructural and morphometric study of the liver of normal and copper-poisoned sheep. Am. J. Pathol. 99(2):429-450. <PMid:7377289>

Gooneratne S.R., Howell J.McC. \& Aughey E. 1986. An ultrastructural study of the kidney of normal, copper poisoned and thiomolybdate treated sheep. J. Comp. Path. 96(6):593-612. <http://dx.doi.org/10.1016/00219975(86)90057-5>

Gould L. \& Kendall N.R. 2011. Role of the rumen in copper and thiomolybdate absortion. Nutr. Res. Rev. 24(2):176-182. <http://dx.doi.org/10.1017/ S0954422411000059><PMid:22296933>

Grace N. \& Knowles S. 2015. Taking action to reduce the risk of copper toxicity in cattle. Vet. Rec. 177(19):490-491.<http://dx.doi.org/10.1136/ vr.h5977> <PMid:26564888>

Gray L.W., Peng F., Molloy S.A., Pendyala V.S., Muchenditsi A., Muzik O., Lee J., Kaplan J.H. \& Lutsenko S. 2012. Urinary copper elevation in a mouse model of Wilson's disease is a regulated process to specifically decrease the hepatic copper load. PloS One. 7(6):e38327.<http://dx.doi.org/10.1371/ journal.pone.0038327><PMid:22802922>
Hamar D.W., Bedwell C.L., Johnson J.L., Schulteiss P.C., Raisbeck M., Grotelueschen D.M., Williams E.S., O’Toole D., Paumer R., Vickers M.G. \& Graham T.J. 1997. Iatrogenic copper toxicosis induced by administering copper oxide boluses to neonatal calves. J. Vet. Diagn. Invest. 9(4):441-443. <http://dx.doi. org/10.1177/104063879700900422><PMid:9376442>

Han H., Archibeque S.L. \& Engle T.E. 2009. Characterization and identification of hepatic mRNA related to copper metabolism and homeostasis in cattle. Biol. Trace Elem. Res. 129(1/3):130-136. <http://dx.doi.org/10.1007/ s12011-008-8293-6><PMid:19099205>

Haywood S., Trafford J. \& Loughran M. 1985. Copper toxicosis and tolerance in the rat: IV. Renal tubular excretion of copper. Br.J. Exp. Pathol. 66(6):699-707. $<$ PMid:4084450>

Howell J.M., Blakemore W.F., Gopinath C., Hall G.A. \& Parker J.H. 1974. Chronic copper poisoning and changes in central nervous system of sheep. Acta Neuropathol. 29(1):9-24. <http://dx.doi.org/10.1007/bf00684387> <PMid:4474789>

Hunter A.G., Suttle N., Martineau H.M., Spence M.A., Thomson J.R., Macrae A.I. \& Brown S. 2013. Mortality, hepatopathy and liver copper concentrations in artificially reared Jersey calves before and after reductions in copper supplementation. Vet. Rec. 172(2):46. <http://dx.doi.org/10.1136/ vr.101051><PMid:23180151>

IBGE. Instituto Brasileiro de Geografia Estatística. 2017. Censo agropecuário: resultados preliminares.

IMEA. Instituto Mato-Grossense de Economia Agropecuária. 2019. 1ํㅗำ Levantamento das intenções de confinamento em 2019.

Johnston H., Beasley L. \& Macpherson N. 2014. Copper toxicity in a New Zealand dairy herd. Ir. Vet. J. 67(1): 20. <http://dx.doi.org/10.1186/20460481-67-20 > <Mid:25279139>

Kendall N.R., Holmes-Pavord H.R., Bone P.A., Ander E.L. \& Young S.D. 2015. Liver copper concentrations in cull cattle in the UK: are cattle being copper loaded? Vet. Rec. 177(19):493. <http://dx.doi.org/10.1136/vr.103078>

Littledick E.T., Wittum T.E. \& Jenkins T.G. 1995. Effect of breed, intake, and carcass composition on the status of several macro and trace minerals of adult beef cattle. J. Anim. Sci. 73(7):2113-2119. <http://dx.doi. org/10.2527/1995.7372113x>

López-Alonso M., Carbajales P., Miranda M. \& Pereira V. 2017. Subcellular distribution of hepatic copper in beef cattle receiving high copper supplementation. J. Trace Elem. Med. Biol. 42: 111-116. <http://dx.doi. org/10.1016/j.jtemb.2017.05.001> <PMid:28595783>

López-Alonso M., Crespo A., Miranda M., Castillo C., Hernández J. \& BeneditoJ.L. 2006. Assessment of some blood parameters as potential markers of hepatic copper accumulation in cattle. J. Vet. Diagn. Invest. 18(1):71-75. <http://dx.doi.org/10.1177/104063870601800109><PMid:16566259>

López-Alonso M.C., Hernández J.\& Shore R.F. 2000. The effect of pig farming on copper and zinc accumulation in cattle in Galicia (North-Western Spain). Vet. J. 160(3):259-266. <http://dx.doi.org/10.1053/tvjl.2000.0503>

Lucena R.B., Pierezan F., Kommers G.D., Irigoyen L.F., Fighera R.A. \& Barros C.LS. 2010. Doenças de bovinos no sul do Brasil. Pesq. Vet. Bras. 30(5):428434. <http://dx.doi.org/10.1590/S0100-736X2010000500010>

Malafaia P., Costa R.M., Brito M.F., Peixoto P., Barbosa J.D., Tokarnia C.H. \& Döbereiner J. 2014. Equívocos arraigados no meio pecuário sobre deficiências e suplementação minerais em bovinos no Brasil. Pesq. Vet. Bras. 34(3):244249. <http://dx.doi.org/10.1590/S0100-736X2014000300008>

Minervino A.H., Barrêto Júnior R.A, Ferreira R.N, Rodrigues F.A, Headley S.A, Mori C.S \& Ortolani E. L. 2009. Clinical observations of cattle and buffalos with experimentally induced chronic copper poisoning. Res. Vet. Sci. 87(3):473478. <http://dx.doi.org/10.1016/j.rvsc.2009.05.002><PMid:19487001>

Miranda M., Gutiérrez B., Benedito J.L., Blanco-Penedo I., García-Vaquero M. \& López-Alonso M. 2010. Influence of breed on blood and tissue copper status in growing and finishing steers fed diets supplemented with copper. Arch. Anim. Nutrin. 64(2):98-110.<http://dx.doi.org/10.1080/17450390903461576> <PMid:20481349> 
Morgan P., Grace N. \& Lilley D. 2014. Using sodium molybdate to treat chronic copper toxicity in dairy cows: a practical approach. N. Z. Vet. J. 62(3):167-170. <http://dx.doi.org/10.1080/00480169.2013.862150> $<$ PMid:24215634>

Mylrea P.J. \& Byrne D.T. 1974. An outbreak of acute copper poisoning in calves. Aust. Vet. J. 50(4):169-172. <http://dx.doi.org/10.1111/j.1751-0813.1974. tb06885.x> <PMid:4471312>

Newcomer B.W., Wolfe D., Chamorro M., Passler T. \& Joiner K. 2016. A suspected case of hepatogenous chronic copper toxicity in a Charolais heifer. Vet. R. 4(1):1-3. <http://dx.doi.org/10.1136/vetreccr-2015-000252>

Newman S.J. 2013. 0 Sistema Urinário, p.592-662. In: In: Zachary, J.F. \& McGavin, M.D., Bases da Patologia em Veterinária. $5^{\underline{a}}$ ed. Elsevier, Rio de Janeiro.

Perrin D. J., Schiefer H. B. \& Blakley B. R. 1990. Chronic copper toxicity in a dairy herd. Can. Vet. J. 31(9): 629-632. <PMid:17423660>

Perrone R.D., Madias N.E. \& Levey A.S. 1992. Serum creatinine as an index of renal function: new insights into old concepts. Clin. Chem. 38(10):19331953. <PMid:1394976>

Rondelli L.A.S., Silva G.S., Bezerra K.S., Rondelli A.L.H., Lima S.R., Furlan F., Pescador C.A. \& Colodel E.M. 2017. Doenças de bovinos em Mato Grosso diagnosticadas no Laboratório de Patologia Veterinária da UFMT (20052014). Pesq. Vet. Bras. 37(5):432-440. <http://dx.doi.org/10.1590/ s0100-736x2017000500002>

Rosa D.E. \& Mattioli G.A. 2002. Metabolismo y deficiencia de cobre en los bovinos. Analecta Vet. 22(1):7-16.

Rosa F.B., Rubin M.I.B., Martins T.B., Gomes D.C., Lemos R.A.A., Massena M.D.B., Marques G.M. \& Barros C.L.S. 2016. Hepatogenous chronic copper toxicosis associated with grazing Brachiaria decumbens in a goat. Braz. J. Vet Pathol. 9(3):113-117.

Silva L.F.C, Valadares-Filho S.C., Rotta P.P., Marcondes I.M., Zanetti D., Gionbelli M.P., Engle T.E. \& Pulino M.F. 2016. In: Valadares-Filho S.C., Silva L.F.C., Gionbelli M.P., Rotta P.P., Marcondes I.M., Chizzotti M.L. \& Prados L.F. Exigências nutricionais de zebuínos puros e cruzados, BR-CORTE, p. 221-248. 3aㅡ ed. UFV, Viçosa.

Sinclair L.A. \& Atkins N. 2015. Intake of selected minerals on commercial dairy herds in central and northern England in comparison with requirements. J. Agric. Sci. 153(4):743-752.<https://doi.org/10.1017/S0021859614001026>

Sinclair L.A., Johnson D., Wilson S. \& Mackenzie A.M. 2017. Added dietary sulfur and molybdenum has a greater influence on hepatic copper concentration, intake and performance in Holstein Friesian dairy cows offered a grass silage-rather than corn silage-based diet. J. Dairy Sci. 100(6):4365-4376. <http://dx.doi.org/10.3168/jds.2016-12217><PMid:28365110>

Skalny A.V., Salnikova E.V., Burtseva T.I., Skalnaya M.G. \& Tinkov A. 2019. Zinc, copper, cadmium, and lead levels in cattle tissues in relation to different metal levels in ground water and soil. Environ. Sci. Pollut. Res. Int. 26(1):559-569. <http://dx.doi.org/10.1007/s11356-018-3654-y> $<$ PMid:30411286>

Souza R.I.C., Santos A.C., Ribas N.L.K.S., Colodel E.M., Leal P.V., Pupin R.C., Carvalho N.M. \& Lemos R.A.A. 2015. Doenças tóxicas de bovinos em Mato Grosso do Sul. Semina: Ciênc. Agrár. 36(3):1355-1368. <http://dx.doi. org/10.5433/1679-0359.2015v36n3p1355>

Steffen D.J., Carlson M.P. \& Casper H.H. 1997. Copper toxicosis in suckling beef calves associated with improper administration of copper oxide boluses. J. Vet. Diagn. Invest. 9(4):443-446. <http://dx.doi. org/10.1177/104063879700900423><PMid:9376443>

Sullivan J.M., Janovitz E.B. \& Robinson F.R. 1991. Copper toxicosis in veal calves. J. Vet. Diagn. Invest. 3(2):161-164. <http://dx.doi. org/10.1177/104063879100300211 > <PMid:1892934>

Suttle N.F. 1974. Effects of organic and inorganic Sulphur on the availability of dietary copper to sheep. Br.J. Nutr. 32(3):559-568. <http://dx.doi. org/10.1079/BJN19740109><PMid:4433503>

Suttle N.F. 2010. Copper, p.255-305. In: Ibid (Ed.), Mineral Nutrition of Livestock. 4th ed. London, CABI.

Suttle N.F., Martineau H.M., Hunter A.G., Thomas J.R. \& Macrae A. 2013. Atypical copper poisoning in Jersey dairy herds. Vet. Rec. 172(3):82-83. <http://dx.doi.org/10.1136/vr.f335> <PMid:23335688>

Tapia L., González-Agüero M., Cisternas M.F., Suazo M., Cambiazo V., Uauy R. \& González M. 2004. Metallothionein is crucial for safe intracellular copper storage and cell survival at normal and supra-physiological exposure levels. Biochem. J. 378(2):617-624. <http://dx.doi.org/10.1042/BJ20031174> <PMid:14627437>

Thrall M.A., Weiser G., Allison R.W. \& Campbell T.W. 2014. Avaliação da função renal, p.286. In: Ibid (Eds), Hematologia e Bioquímica Veterinária. $2^{\underline{a}}$ ed. Roca, São Paulo.

Tokarnia C.H., Döbereiner J., Peixoto P.V. \& Moraes S.S. 2000. Outbreak of a copper poisoning in cattle fed poultry litter. Vet. Hum. Toxicol. 42(2):92-95. <PMid:10750174>

Tokarnia C.H., Peixoto P.V., Barbosa J.D., Brito M.F. \& Döbereiner J. 2010. Intoxicação por cobre, p.103-105. In: Ibid (Eds), Deficiências Minerais em Animais de Produção. Helianthus, Rio de Janeiro.

Tremblay R.R. \& Baird J.D. 1991. Chronic copper poisoning in two Holstein cow. Cornell Vet. 81(2):205-213. <PMid:2029843>

Underwood E.J. \& Suttle N.F. 1999. The mineral nutrition of livestock. 614p. 3 ed. Cabi publishing, Wallingford.

Underwood E.J. 1977. Trace elements in human and animal nutrition. 560p. 4 ed. Academic press, New York.

Valli V.O. 2007. Hematopoietic System. In: Maxie M.G. (ED.). Jubb, Kennedy, and Palmer's Pathology Of Domestic Animals, p.107-324. V.3, 5th Ed, Saunders Elsevier, Philadelphia.

Wang X., Wang H., Li J., Yang Z., Zhang J., Qin Z., Wang L. \& Kong X. 2014. Evaluation of bioaccumulation and toxic effects of copper on hepatocellular structure in mice. Biol. Trace Elem. Res. 159(1/3):312-319. <http://dx.doi. org/10.1007/s12011-014-9970-2><PMid:24763709>

Zhao H., Wang Y., Fei D., Guo M., Yang X., Mu M., Yu H. \& Xing M. 2019. Destruction of redox and mitochondrial dynamics co-contributes to programmed cell death in chicken kidney under arsenite or/and copper (II) exposure. Ecotoxicol. Environ. 179:167-174. <http://dx.doi.org/10.1016/j. ecoenv.2019.04.062> <PMid:31039459>

Zischka H., Lichtmannegger J., Schmitt S., Jägemann N., Schulz S., Wartini D., Jennen L., Rust C., Larochette N., Galluzzi L., Chajes V., Bandow N., Gilles V.S., Di Spirito A.A., Esposito I., Goettlicher M., Summer K.H. \& Kroemer G. 2011. Liver mitochondrial membrane crosslinking and destruction in a rat model of Wilson disease. J. Clin. Invest. 121(4):1508-1518. <http:// dx.doi.org/10.1172/JCI45401> <PMid:21364284> 